\title{
Effectiveness of the Art of Living YES! Programme on School Students
}

\author{
Sweta Sharadkumar Chauhan ${ }^{1}$
}

\section{ABSTRACT:}

Peer Pressure is very much common during Examination, sports and entrance tests. It is experienced in human relations too. So how can we cope with everything? The Art of Living YES! (The Youth Empowerment Seminar) programme is a life skills programme. It is composed of three modules: Healthy Body, Healthy Mind and Healthy Lifestyle. The Art of Living YES! Programme is based on- Sudarshan Kriya, Meditation and breathing techniques, Techniques for mental focus and concentration, Techniques for overcoming fear and anxiety, Interactive process, team games, Food awareness, Group discussions, Learning through fun and games, service to others, confidence building and leadership. YES! programme was applied by the Art of Living teacher. The researcher developed a rating scale for measuring YES! programme. Post test only experimental group design was used in this research. The students of SSRVM School, VallabhVidyanagar made the population for the study. For content analysis X2 was found out and interpretation is derived from the result. School students have shown positive tendency about YES! programme. Students were more positive. YES! programme was found more effective on the students of SSRVM School. It is suggested that such progammes can be implemented on various groups at Schools to enhance the positive life skills and better living and life style.

Keywords: Art of Living, Effectiveness, School Students

Peer Pressure is very much common during Examination, sports and entrance tests. It is experienced in human relations too. The ability to cope with stress, its management and elimination of its effects are becoming consideration the problems related to the consequences of today life style, artificially created environment. So how can we cope with everything?

The Art of Living YES!( The Youth Empowerment seminar) programme is a life skills programme. It is composed of three modules: Healthy Body, Healthy Mind and Healthy Lifestyle.

\footnotetext{
${ }^{1}$ Asst. Professor, Bavisgam B.Ed. College, Sardar Patel University, Vallabh Vidyanagar
} 


\section{Effectiveness of the Art of Living YES! Programme on School Students}

One of the key characteristics of the educational programs offered by the foundation is giving practical knowledge, techniques and skills that help people cope with stress and stressful situation, remove their influences and handle more efficiently with different tasks and demands in daily life, while at the same time improving health and achieving better quality of life.

\section{- The Art of Living Foundation:}

"My Vision is a Stress-free, Violence free world"

\section{- Sri SriRavishankar}

Sri SriRavishankarji is a humanitarian and spiritual leader, an ambassador of peace and human values. He found The Art of Living Foundation, one of the largest international non-government organization Through his work, Sri Sri has inspired millions of people around the world with a vision of a stress-free, violence-free world. He has founded courses that provide techniques and tools to live a deeper, more joyous life and he has established nonprofit organization that recognize a common human identity above the boundaries at race, nationality and religion.

\section{- The Art of Living YES! Programme:}

YES! is a programme based on life skills. It is composed of three modules:

- Healthy Body

- Healthy Mind

- Healthy Lifestyle

\section{- Healthy Body:}

The health body module consists of physical activity that includes yoga stretches, mindful eating processes and interactive discussions about food and nutrition.

\section{- Healthy Mind:}

The healthy mind module includes stress management and relaxation techniques. Breathing exercises (eg.,SudarshanKriya) and mindfulness techniques are used to calm the mind, bringing awareness to the moment and enhancing concentration. Group processes promote personal responsibility respect, honesty, and service to others.

\section{- Healthy Lifestyle:}

In the healthy Lifestyle module students learn strategies for handling challenging emotional and social situations, especially peer pressure. Mindful decision making and leadership skills are taught via interactive games come and see the world from a different point of view.

\section{- YES! Programme contents:}

The Art of Living YES! Programme is based on

- SudarshanKriya, Meditation and breathing techniques, Techniques for mental focus and concentration, Techniques for overcoming fear and anxiety, Interactive process, team games, Food awareness, Group discussions, Learning through fun and games, service to others, confidence building and leadership. 
OVERVIEW OF THE PROGRAMME:

- Age Group : : 14 to 17 Years

- Course duration : 4 to 6 days

- Time Per day: 3 to 4 hours.

RESEARCH QUESTIONS:

- What is YES! programme?

- How could the YES! Programmebe useful for students?

- What will be the effect of YES! Programme on student's behavior?

\section{OBJECTIVES OF THE STUDY:}

- To construct rating scale for measuring YES! programme.

- To try-out YES! programme in School.

- To study the effectiveness of YES! programme through quantitative analysis.

- To derive educational implications and make recommendation for YES! programme.

RESEARCH METHODOLOGY:

- YES! programme was applied by the Art of Living teacher.

- The researcher developed a rating scale for measuring YES! programme. The data was collected and processed by statistical analysis and interpretations are derived.

- Post test only experimental group design was used in this research.

\section{- Population and Sample:}

The students of Sri Sri Ravishankar Vidya Mandir, Vallabh Vidyanagar made the population for the study. 40 students were given a rating scale. This was a sample for the study. which was random representative sample.

\section{- Construction of a Tool:}

The researcher had constructed a rating scale comprised of Attributes. After expert's opinions ten attributes were included in this rating scale. The rating scale was administered on students after the programme.

-Statistical Data Analysis:

For content analysis $\mathrm{X}^{2}$ was found out and interpretation is derived from the result.

School students understanding about YES! programme

\begin{tabular}{|l|l|l|l|l|l|l|l|l|}
\hline No. & \multicolumn{1}{|c|}{ Attributes } & A & B & C & D & E & $\mathbf{X}^{\mathbf{2}}$ Value & Sign. \\
\hline 1. & SudarshanKriya & 27 & 06 & 06 & 00 & 01 & 60.24 & $* *$ \\
\hline 2. & Peace of Mind & 23 & 11 & 04 & 02 & 00 & 43.74 & $* *$ \\
\hline 3. & Patience & 20 & 13 & 04 & 03 & 00 & 34.24 & $* *$ \\
\hline 4. & Perception & 19 & 14 & 06 & 01 & 00 & 34.24 & $* *$ \\
\hline 5. & Leadership & 25 & 10 & 04 & 01 & 00 & 52.74 & $* *$ \\
\hline 6. & Creativity & 22 & 12 & 05 & 01 & 00 & 41.74 & $* *$ \\
\hline 7. & Dynamism & 24 & 10 & 04 & 02 & 00 & 47 & $* *$ \\
\hline 8. & Team Work & 25 & 11 & 03 & 01 & 00 & 54.48 & $* *$ \\
\hline 9. & Observation & 23 & 13 & 04 & 00 & 00 & 49.24 & $* *$ \\
\hline 10. & Confidence building & 25 & 14 & 01 & 00 & 00 & 62.74 & $* *$ \\
\hline
\end{tabular}

*indicates significance at 0.05 level. 
**does not indicate significance at 0.05 level

$\mathrm{df}=4$, at 0.05 level sign. value is 9.488 .

$\begin{array}{lll}\mathrm{A} & = & \text { Strongly Agree } \\ \mathrm{B} & = & \text { Agree } \\ \mathrm{C} & = & \text { Uncertain } \\ \mathrm{D} & = & \text { Disagree } \\ \mathrm{E} & = & \text { Strongly Disagree. }\end{array}$

For the attributes 1 to 10 the value of $\mathrm{X}^{2}$ at $\mathrm{df}=4$ and at 0.05 level the calculated $\mathrm{X}^{2}$ value > table value. Hence it can be said that difference is significant. The null hypothesis is rejected. So the data is not normally distributed.

From above analysis it could be interpreted that the School students had not given their choice at random. Hence specific opinions on positive YES!programme are generated from their chosen frequencies.

\section{FINDINGS OF THE STUDY:}

- The school students' responses for the attributes of rating scale has generated specific opinions. Their level of understanding about YES! programme from statistical interpretation of $\mathrm{X}^{2}$ is showing general choice about attributes.

- School students have shown positive tendency about YES! programme.

\section{CONCLUSION:}

The Art of Living YES! programme are based on unique approach, process of social interaction, the use of breath as a link between human mental state and situation they face. Students were more positive. YES!programme was found more effective on the students of SSRVM School.

It is suggested that such progammes can be implemented on various groups at Schools to enhance the positive life skills and better living and life style.

\section{REFERENCES}

1. Andrej Trampur, MajaTrampuz, R.P. Research on the effects of The Art of Living antistress program. The possibility of their contribution to managing stress in the slovenian armed forces.

2. www.artofliving.org.

3. www.jahonline.org. 